\title{
EFEKTIVITAS PUPUK ORGANIK CAIR (POC) CANGKANG TELUR DAN AIR KELAPA TERHADAP PERTUMBUHAN RUMPUT GAJAH MINI (Pennisetum purpureum)
}

\section{Effectiveness of Organic Liquid Fertilizer from Egg Shell and Coconut Water on The Growth of Gajah Mini Grass (Pennisetum purpureum)}

\author{
Aminuddin Saade*, Idris, dan Andi Fachrizal \\ Politeknik Pembanguan Pertanian Gowa \\ *e-mail: aminsaade.63@gmail.com
}

Received: 10 September 2021; Accepted: 10 November 2021; Published: 25 Desember 2021

\begin{abstract}
ABSTRAK
Kajian ini dilaksanakan di Kampus Poloteknik Pembangunan Pertanian (Polbangtan) Gowa pada Bulan Mei sampai Bulan Juli 2021, dan penyuluhan dilaksanakan pada Kelompok Tani Palampang Raya di desa Pabbentengang, Kecamatan Bajeng, Kabupaten Gowa. Kajian ini bertujuan untuk mengetahui efektivitas pupuk organik cair (poc) cangkang telur dan air kelapa terhadap pertumbuhan rumput gajah mini, dan untuk mengetahui perubahan tingkat pengetahuan, keterampilan dan sikap peternak terhadap efektivitas pupuk organik cair (poc) cangkang telur dan air kelapa terhadap pertumbuhan rumput gajah mini. Metode kajian disusun dengan menggunakan Mirosoft Excel 2010 yang dilanjutkan dengan Uji BNT, yang terdiri dari empat perlakuan dan empat ulangan sehingga diperoleh 16 sampel. Perlakuan P0 (tanpa perlakuan POC), P1 (POC cangkang telur dan air kelapa $150 \mathrm{~mL} /$ liter air), P2 (POC cangkang telur dan air kelapa 250 $\mathrm{mL} /$ liter air), P3 (POC cangkang telur dan air kelapa $350 \mathrm{~mL} /$ liter air). Hasil menunjukkan bahwa perlakuan P3 (POC cangkang telur dan air kelapa $350 \mathrm{~mL} /$ liter air) memberikan hasil terbaik pada tinggi tanaman $(75,1 \mathrm{~cm})$, panjang daun $(46,36 \mathrm{~cm})$ dan lebar daun $(2,53 \mathrm{~cm})$, perlakuan P1 (POC cangkang telur dan air kelapa $150 \mathrm{~mL} /$ liter air) memberikan hasil terbaik pada jumlah anakan (2,73 anakan).
\end{abstract}

Kata kunci: Cangkang telur, air kelapa, rumput gajah mini

\begin{abstract}
This research was held at Agriculture Development Polytechnic (Polbangtan) Gowa on May until July 2021, and the socialization was done to Palampang Raya Farmer Group in Pabbentengang village, Bajeng District, Gowa Regency. This study aims to determine the effectiveness of organic fertilizer (POC) eggshell and coconut water on the mini elephant grass growth and to determine the changes of the farmer's knowledge, skills and attitude on the effectiveness of POC eggshell and coconut water to the mini elephant grass. The research method is prepared with Microsoft Excel 2010 and continued with BNT Test which consisted of four treatments and four replications to get 16 samples in result. P0 treatment (Without POC), P1 (POC eggshell and coconut water $150 \mathrm{~mL} /$ liter water), P2 (POC eggshell and coconut water 250 $\mathrm{mL} /$ liter water), P3 (POC eggshell and coconut water $350 \mathrm{~mL} /$ liter water). The result showed that P3 treatment (POC eggshell and coconut water $350 \mathrm{~mL} /$ liter water ) give the best result on plant height $(75,1$ $\mathrm{cm})$, leaf length $(46,36 \mathrm{~cm})$ and leaf width $(2,53 \mathrm{~cm}), P 1$ treatment (POC eggshell and coconut water 150 $\mathrm{mL} /$ liter water) give the best result on the number of tillers (2,73 tillers).
\end{abstract}

Keywords: Eggshell, coconut water, mini elephant grass 


\section{PENDAHULUAN}

Hijauan merupakan faktor penting dalam pengembangan ternak ruminansia untuk bertahan hidup, berproduksi, serta berkembang biak. Penyediaan pakan yang cukup dan kualitas nutirsi yang baik akan menunjang produksi ternak. Salah satu hijauan yang memiliki nutrisi yang tinggi yaitu rumput gajah mini (Pennisetum purpureum cv. mott).

Rumput gajah mini merupakan jenis rumput unggul yang mempunyai produktivitas dan kandungan zat gizi yang cukup tinggi serta memiliki palatabilitas yang tinggi bagi ternak ruminansia. Untuk memenuhi ketersediaan rumput gajah mini yang cukup dan bernutrisi tinggi maka dilakukan pemupukan. Pemupukan dilakukan untuk menyediakan unsur hara yang dibutuhkan oleh tanaman dalam setiap periode tumbuhnya. Salah satu pupuk yang dapat digunakan untuk meningkatkan unsur hara pada tanah adalah pupuk organik cair.

Pupuk organik cair menurut Hadisuwito (2012) adalah larutan dari pembusukan bahanbahan organik yang berasal dari sisa tanaman, kotoran hewan dan manusia yang kandungan haranya lebih dari satu unsur. POC lebih diutamakan pengaplikasiannya untuk melengkapi kebutuhan nutrisi tanaman melalui daun. Pupuk organik cair mengandung $\mathrm{C}$-Organik tinggi, hara makro dan mikro (N, P, K, Ca, Mg, B, Zn, Cu, $\mathrm{Mn}, \mathrm{Co}, \mathrm{Bo}, \mathrm{Mo}, \mathrm{Fe})$. Pupuk organik cair ini mempunyai beberapa manfaat diantaranya merangsang pertumbuhan dan kualitas kinerja akar secara sempurna serta meningkatkan perkembangan dan pertumbuhan tanaman secara total (Hamzah, 2014).

Limbah peternakan yang dapat dimanfaatkan sebagai pupuk organik cair adalah cangkang telur. Limbah cangkang telur ayam boiler sebenarnya dapat dimanfaatkan dengan diolah menjadi pupuk organik cair karena mengandung unsur hara yang dibutuhkan tanaman seperti kalsium karbonat, nitrogen, kalium dan fosfor (Emi dkk, 2017). Cangkang telur ayam broiler mengandung 97\% kalsium karbonat serta mengandung rerata 3\% fosfor dan $3 \%$ magnesium, natrium, kalium, seng, pangan, besi dan tembaga. Kandungan cangkang telur ayam boiler terdiri dari kalium sebesar $0,121 \%$; kalsium sebesar 8,977\%; fosfor sebesar 0,394\% dan magnesium sebesar 10,541\%. Kandungan kalsium pada cangkang telur ayam boiler yang cukup besar inilah yang dimanfaatkan sebagai pupuk organik cair bagi tanaman (Ratnasari, 2015).

Air kelapa diketahui mengandung vitamin $\mathrm{C}$, asam nikotianat, asam folat, asam pantotenat, biotin, riboflavin (Yunita, 2011 dalam Trisna et al. (2013). Selain itu juga banyak mengandung hormon tumbuhan seperti giberelin, sitokinin, dan auksin serta kaya akan kalium, kalsium dan nitrogen. Berbagai kandungan ini sangat bermanfaat untuk memacu pertumbuhan tanaman. Selain digunakan langsung, air kelapa dapat diolah menjadi pupuk organik cair melalui proses fermentasi. Pemberian pupuk organik bermanfaat untuk meningkatkan kandungan hara dan bahan organik tanah serta memperbaiki sifat fisik, kimia, dan biologi tanah (Permentan No. 70/Permentan/SR.140/10/2011). Serta sangat berguna dalam peningkatan produksi pertanian baik kualitas maupun kuantitas serta mengurangi pencemaran lingkungan (Simanungkalit, 2010). Berdasarkan latar belakang ini, maka penulis melakukan kajiwidya yang bertujuan untuk mengetahui pengaruh pemberian POC Cangkang Telur dan Air Kelapa terhadap Pertumbuhan Rumput Gajah Mini.

\section{METODE PENELITIAN}

\section{Waktu dan Tempat}

Penelitian dilaksanakan pada bulan April - Juni 2021 dimana pengkajian bertempat di kampus Politeknik Pembangunan Pertanian (Polbangtan) Gowa di Kecematan Bontomarannu, Kabupaten Gowa dan penyuluhan dilaksanakan di Desa Pabbentengang, Kecamatan Bajeng, Kabupaten Gowa, Provinsi Sulawesi Selatan, Indonesia.

\section{Bahan dan Alat}

Bahan yang digunakan yaitu stek rumput gajah mini, cangkang telur, air kelapa muda, Effective Mikroorganisme (EM4), gula pasir, polybag, dan label. Sedangakan bahan yang digunakan untuk kegiatan penyuluhan yaitu kuisioner, lembar persiapan menyuluh (LPM), benda sesungguhnya, power point dan folder. Alat yang digunakan yaitu blender, jirigen, sprayer, pengayak, timbangan, penggaris, gelas ukur, dan alat tulis. Sedangkan alat yang digunakan untuk kegiatan penyuluhan yaitu Laptop, proyektor dan kamera untuk mendokumentasikan kegiatan. 


\section{Metode}

Penelitian ini dilakukan dengan menggunakan Rancangan Acak Kelompok (RAK) dengan 4 perlakuan dan 4 ulangan, sehingga mmenghasilkan 16 sampel, setiap sampel ditanami 3 stek sehingga jumlah stek yang digunakan yaitu 48 stek dengan pemberian dosis POC yang berbeda setiap perlakuan. $\mathrm{P} 0=$ Tanpa POC Cangkang telur dan Air Kelapa (kontrol) P1 = POC Cangkang telur dan Air Kelapa 150ml / 1 liter air P2 = POC Cangkang telur dan Air Kelapa 250ml / 1 liter air P3 = POC Cangkang telur dan Air Kelapa 350ml / 1 liter air

\section{Pelaksanaan}

Pelaksanaan kajian ini diawali dengan menyiapkan alat dan bahan seperti stek rumput gajah mini, cangkang telur, air kelapa muda, Effective Mikroorganisme (EM4), gula merah, polybag, label, blender, jirigen, sprayer, pengayak, timbangan, penggaris, gelas ukur, dan alat tulis. Setelah semua sudah siap maka hal yang pertama dilakukan yaitu membuat POC cangkang telur dan air kelapa.

Cangkang telur yang akan digunakan dicuci terlebih dahulu dengan air kemudian dipisahkan dari membran bagian dalam dan dijemur selama satu hari dengan sinar matahari. Cangkang telur ayam yang sudah kering kemudian dihaluskan dengan menggunakan blender hingga menjadi serbuk cangkang telur kemudian diayak dengan ukuran 100 mesh.

Menyiapkan volume total sebanyak $3 \mathrm{~kg}$ bubuk cangkang telur yang sudah dihaluskan, dengan 4 perlakuan dan 4 kali pengulangan. Setiap perlakuan dilakukan 4 kali penyiraman setelah penyeragaman. Peneliti menyiapkan air kelapa sebanyak $3.000 \mathrm{ml}$, air cucian beras sebanyak $200 \mathrm{ml}$, EM4 sebanyak $50 \mathrm{ml}$ dan gula merah yang telah dicairkan sebanyak $50 \mathrm{ml}$. Campurkan bahan-bahan tersebut kedalam sebuah wadah (jirigen), lalu diamkan selama 7 hari. Selama proses fermentasi wadah dibuka setiap hari untuk aerasi dan juga membebaskan gas yang diproduksi selama proses berlangsung.

Pemberian POC dilakukan setiap minggu sekali pada pagi hari selama 4 minggu setelah penyeragaman. Penyeragaman dilakukan selama 2 minggu, setelah itu dilakukan pemotongan 2-4 ruas yang akan dijadikan bibit. Pengukuran dan perhitungan tinggi tanaman, pajang daun, lebar daun, jumlah anakan dilakukan setiap minggu setelah pemberian POC pertama sebanyak 4 kali.

\section{Analis Data}

Kajian ini bertujuan untuk mengetahui ada tidaknya perbedaan nyata setiap perlakuan terhadap pemberian POC Cangkang Telur dan Air Kelapa. Metode analisis data yang digunakan dalam kajian ini yaitu data yang diperoleh diolah dengan sidik ragam sesuai dengan Rancangan Acak Kelompok (RAK). Analisis data yang digunakan adalah Uji F (analisis varians) dengan rumus.

Keterangan:

$$
\mathrm{Yij}=\mu+\tau \mathrm{i}+\varepsilon \mathrm{ij}
$$

Yij = respon atau nilai pengamatan dari perlakuan ke-i dan ulangan ke-j

$\mu=$ nilai tengah umum

$\mathrm{Ti}=$ pengaruh perlakuan ke-i

$\varepsilon i j=$ pengaruh galat percobaaan dari perlakuan ke-i dan ulangan ke-j

Jika ada perbedaan yaitu pengaruh nyata atau sangat nyata maka dilanjutkan dengan uji beda nyata terkecil (BNT).

\section{Parameter Pengamatan}

Hal-hal yang diamati selama berlangsungnya penelitian yaitu Tinggi tanaman (cm) diukur dari pangkal batang diatas permukaan tanah sampai titik tumbuh teratas dan diamati sekali seminggu. Jumlah Anakan, dihitung semua Anakan yang terbentuk dan diamati sekali seminggu. Panjang daun $(\mathrm{cm})$, diukur dari pangkal daun sampai ujungnya. Satu daun mewakili satu polybag, diamati sekali seminggu. Lebar daun $(\mathrm{cm})$, diukur menggunakan panggaris atau leaf area meter. Satu daun mewakili satu polybag, diamati sekali seminggu.

\section{HASIL DAN PEMBAHASAN}

Hasil kajian yang diperoleh berupa tinggi tanaman, panjang daun, lebar daun dan jumlah anakan pada pengaplikasian pupuk organik cair (POC) cangkang telur dan air kelapa terhadap pertumbuhan rumput gajah mini. Pengujian POC ini menggunakan 4 kelompok perlakuan yang memiliki konsentrasi POC yang berbeda dan dilakukan 4 kali ulangan. Pengujian 4 kelompok perlakuan yaitu $(\mathrm{P} 0, \mathrm{P} 1, \mathrm{P} 2, \mathrm{P} 3) . \mathrm{P} 0=$ tanpa perlakuan, $\mathrm{P} 1=150 \mathrm{ml} / 1$ liter air, $\mathrm{P} 2=250 \mathrm{ml} /$ 1 liter air, dan $\mathrm{P} 3=350 \mathrm{ml} / 1$ liter air. 

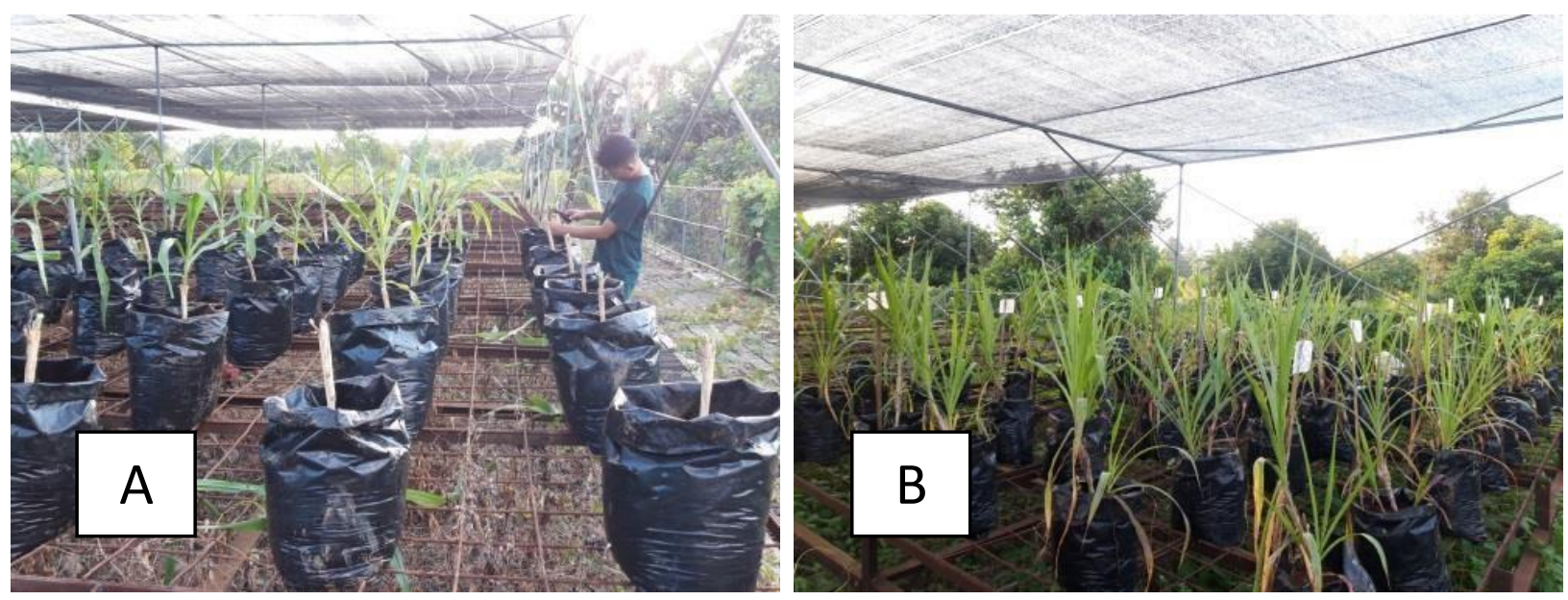

Gambar 4. Gambar (A) satu hari setelah penyeragaman dan (B) setelah umur 28 hari

Data pengamatan dan hasil analisis diuji dengan metode uji statistic One Way Anova dengan Aplikasi Microsoft Excel 2010, dan data yang signifikan selanjutnya diteruskan menggunakan uji Beda Nyata Terkecil; (BNT) . Uraian hasil dari parameter yang diamati dapat dilihat pada tabel 1. Berdasarkan tabel 1 menunjukkan bahwa hasil analisis pada pengaplikasian POC cangkang telur dan air kelapa memberikan pengaruh nyata terhadap tinggi tanaman. Terlihat pada uji lanjut BNT bahwa P1, P2, P3 berbeda nyata dengan P0, tetapi P1, P2 dan P3 saling tidak berbeda nyata secara signifikan.

Tabel 1. Rata-rata hasil parameter yang diamati

\begin{tabular}{clcccc}
\hline No & Parameter & P & P1 & P2 & P3 \\
\hline 1 & Tinggi tanaman & $68,50 \mathrm{a}$ & $74,75 \mathrm{~b}$ & $74,75 \mathrm{~b}$ & $75,10 \mathrm{~b}$ \\
2 & Panjang daun & $41,48 \mathrm{a}$ & $45,58 \mathrm{a}$ & $45,70 \mathrm{a}$ & $46,36 \mathrm{a}$ \\
3 & Lebar daun & $2,35 \mathrm{a}$ & $2,52 \mathrm{a}$ & $2,58 \mathrm{a}$ & $2,59 \mathrm{a}$ \\
4 & Jumlah Anakan & $2,08 \mathrm{a}$ & $2,73 \mathrm{a}$ & $2,15 \mathrm{a}$ & $2,71 \mathrm{a}$ \\
\hline
\end{tabular}

Ket. Huruf yang berbeda pada baris yang sama menunjukkan perbedaan nyata $(\mathrm{P}<0.05)$

Berdasarkan hasil uji yang telah dilakukan dapat dilihat dari empat kelompok perlakuan dengan empat kali ulangan, tinggi tanaman rumput gajah mini paling tinggi pada pemberian $350 \mathrm{ml} /$ liter air POC cangkang telur dan air kelapa. Panjang daun rumput gajah mini terpanjang pada pemberian $350 \mathrm{ml} /$ liter air POC cangkang telur dan air kelapa. Lebar daun rumput gajah mini terlebar pada pemberian POC cangakng telur dan air kelapa 350m1/liter air, sedangkan jumlah anakan rumput gajah mini paling banyak pada pemberian $150 \mathrm{ml} /$ liter air POC cangkang telur dan air kelapa.

Parameter pada kajian efektifitas pemberian pupuk organik cair cangkang telur dan air kelapa terhadap pertumbuhan tanaman rumput gajah mini (Pennisetum Purpureum CV. Mott) disetiap perlakuan menunjukkan hasil yang berbeda pada tinggi tanaman, panjang daun, lebar daun dan jumlah anakan. Hasil rata-rata penggunaan POC cangkang telur dan air kelapa menunjukkan semakin tinggi dosis pemberian pada tanaman rumput gajah mini maka dapat meningkatkan pertumbuhan tinggi tanaman, panjang daun dan lebar daun. Hal ini disebabkan oleh kandungan kalsium yang terdapat pada cangkang telur, seperti yang dikemukakan (Huda, 2020) bahwa pemberian pupuk organik cair cangkang telur ayam broiler efektif dalam meningkatkan pertumbuhan tinggi tanaman selada, karena tanaman mendapatkan nutrisi dan unsur hara yang cukup untuk proses pertumbuhan dan perkembangannya. Pupuk organik cair cangkang telur ayam boiler mengandung salah satu unsur hara yang dibutuhkan tanaman yaitu kalsium.

Hasil rata-rata penggunaan POC cangkang telur dan air kelapa menunjukkan 
semakin tinggi dosis pemberian pada tanaman rumput gajah mini maka tidak berpengaruh terhadap jumlah anakan, hasil rata-rata jumlah anakan terbaik terdapat pada pemberian 150 $\mathrm{ml} /$ liter air POC cangkang telur dan air kelapa. Hal ini disebabkan oleh kandungan hormon auksin yang terdapat pada air kelapa. Menurut Wattimena (2002) dalam Mufarihin (2006) bahwa auksin sebagai hormon pertumbuhan mempunyai pengaruh fisiologis terhadap aspek perkembangan dan pertumbuhan diantaranya perbesaran sel, pembentukan akar, tingkat konsentrasi auksin yang tidak tidak terlalu tinggi akan merangsang pertumbuhan akar dengan baik.

\section{KESIMPULAN}

Pemberian Pupuk Organik Cair (POC) cangkang telur dan air kelapa terhadap pertumbuhan rumput gajah mini (pennisetum purpureum $c v$. Mott) berpengaruh terhadap tinggi tanaman, panjang daun, lebar daun dan jumlah anakan. Pemberian POC cangkang telur dan air kelapa pada perlakuan (P3) dengan dosis 350 $\mathrm{ml} /$ liter air memberikan hasil rata-rata tertinggi pada tinggi tanaman $(75,1 \mathrm{~cm})$, panjang daun $(46,36 \mathrm{~cm})$ dan lebar daun $(2,53 \mathrm{~cm})$, sedangkan pada perlakuan (P1) dengan dosis pemberian 150 $\mathrm{ml} /$ liter air memberikan rata-rata tertinggi pada jumlah anakan (2,73 anakan).

\section{DAFTAR PUSTAKA}

Emi, Eka Lokaria, dan Harmoko. 2017. Pengaruh Pupuk Serbuk Cangkang Telur Ayam
Ras Terhadap Pertumbuhan Tanaman Sawi Caisim (Brassica Juncea L.). STKIPGRI. Lubuk Linggau.

Hadisuwito, S. 2007. Membuat Pupuk Kompos Cair. PT Agromedia Pustaka. Jakarta.

Hamzah, S. 2014. Pupuk Organik Cair Dan Pupuk Kandang Ayam Berpengaruh Kepada Pertumbuhan Dan Produksi Kedelai (Glycine Max L.). Jurnal Agrium.

Huda, N. 2020. Efektivitas Pupuk Organik Cair Cangkang Telur Ayam Boiler Terhadap Pertumbuhan Selada (Lactuca Sativa) Secara Hidroponik Sebagai Penunjang Praktikum Fisiologi Tumbuhan. Fakultas Tarbiyah Dan Keguruan. Universitas Islam Negeri Ar- Ranirydarussalam. Banda Aceh.

Mufarihin A, dkk. 2012. Pertumbuhan Dan Bobot Bahan Kering Rumput Gajah Dan Rumput Raja Pada Perlakuan Aras Auksin Yang Berbeda. Fakultas Peternakan Dan Pertanian. Universitas Diponegoro. Semarang.

Simanungkalit, R.D.M., Suriadikarta, D.A., Saraswati, R., Setyorini, D., Hartatik, W. 2010. Pupuk Organik Dan Pupuk Hayati. Balai Penelitian dan Pengembangan Pertanian

Trisna, N., Husain, U., dan Irmasari. 2013. Pengaruh Berbagai Jenis Zat Pengatur Tumbuh Terhadap Pertumbuhan Stump Jati (Tectona Grandis). Jurnal Warta Rimba. 